\title{
Decisions and macroeconomics: development and implementation of a simulation game
}

Citation for published version (APA):

Woltjer, G. B. (2003). Decisions and macroeconomics: development and implementation of a simulation game. METEOR, Maastricht University School of Business and Economics. METEOR Research Memorandum No. 002 https://doi.org/10.26481/umamet.2003002

Document status and date:

Published: 01/01/2003

DOI:

10.26481/umamet.2003002

Document Version:

Publisher's PDF, also known as Version of record

\section{Please check the document version of this publication:}

- A submitted manuscript is the version of the article upon submission and before peer-review. There can be important differences between the submitted version and the official published version of record.

People interested in the research are advised to contact the author for the final version of the publication, or visit the DOI to the publisher's website.

- The final author version and the galley proof are versions of the publication after peer review.

- The final published version features the final layout of the paper including the volume, issue and page numbers.

Link to publication

\footnotetext{
General rights rights.

- You may freely distribute the URL identifying the publication in the public portal. please follow below link for the End User Agreement:

www.umlib.nl/taverne-license

Take down policy

If you believe that this document breaches copyright please contact us at:

repository@maastrichtuniversity.nl

providing details and we will investigate your claim.
}

Copyright and moral rights for the publications made accessible in the public portal are retained by the authors and/or other copyright owners and it is a condition of accessing publications that users recognise and abide by the legal requirements associated with these

- Users may download and print one copy of any publication from the public portal for the purpose of private study or research.

- You may not further distribute the material or use it for any profit-making activity or commercial gain

If the publication is distributed under the terms of Article $25 \mathrm{fa}$ of the Dutch Copyright Act, indicated by the "Taverne" license above, 
Decisions and macroeconomics: development and implementation of a simulation game

\author{
Dr. Geert Woltjer \\ Universiteit Maastricht \\ Department of Economics \\ P.O. Box 616 \\ 6200 MD Maastricht \\ The Netherlands \\ Tel. +31433883651 \\ Fax +31433884878 \\ E-mail: g.woltjer@algec.unimaas.nl
}




\section{Decisions and macroeconomics: development and}

\section{implementation of a simulation game}

\footnotetext{
"Steer the economy" is an interactive game that shows the relationship between company decisions and macroeconomic dynamics. In this real time computer network simulation game the interaction between the players determines the macroeconomic results and players see within a short period the long-term consequences of their strategic decisions.
}

For a lot of students macroeconomics is very abstract. It is difficult for them to imagine that the theories are fundamentally about the coordination of human decisions. A simulation game called "Steer the economy" has been developed that creates the possibility for students to make the decisions of the firms that are implicit in macroeconomic models. The game consists of a computer network where players manage their own company for about 150 months. The players make decisions about price, wage, labor demand, and investment. All players together are the complete production sector of the economy. Consumption, government and the Central Bank are incorporated in the computer model and can be manipulated by the game leader. The computer model is consistent with both neoclassical and Keynesian theory; when the game leader does not interfere, the stability of the economy depends completely on the decisions of the players. While in theory there is a rational expectations equilibrium growth path, it will never happen because of imperfect information. The students have to explain unemployment, inflation, investment, etc., as a consequence of their own decisions and expectations. They can increase the profits of their companies in the game by analyzing micro- and macroeconomic dynamics in the game economy. A system of feedback is necessary to generate the necessary skills.

Key words: macroeconomics, simulation game, unemployment, inflation, investment

JEL code: $A 2$

For most students, macroeconomics is very abstract. Although most courses in macroeconomics include discussions of real world examples and in many cases also some simulation exercises, students have to use abstract concepts like IS curves while they have difficulties to understand their real meaning. Especially, most students are not aware that decisions of human beings are behind the formulas. Therefore, I developed a 
simulation game called "Steer the Economy" where the players make (simplified) decisions of companies and see how the interaction of those decisions generates fluctuations in for example unemployment, inflation, real wages and investment ${ }^{1}$. By playing the game students make all the company decisions and become aware of the interdependence of those decisions between different firms and sectors, something that is only implicitly described in most macroeconomics textbooks.

Microeconomics and macroeconomics are normally taught as more or less independent subjects. A lot of textbooks even start with macroeconomics instead of microeconomics. One reason may be that introductory economics is focused on equilibrium behavior, while the processes of adjustment are something for more advanced courses. A game where dynamic interaction between companies generates macroeconomic and microeconomic developments helps students to become aware of the decision processes involved in micro- and macroeconomic dynamics explained by economic theory.

For most students who don't want to become economists, textbook economic theory seems to be very abstract and irrelevant. This holds especially for students in business. They have the feeling that the assumptions used in economic theory are not consistent with what they learn about business in their study. When those students make the decisions that generate macroeconomic dynamics themselves, they get a better intuition for the relevance of economic analysis. Furthermore, it is very useful for those students to see that their profits can increase when they use analyses of macro- and meso-economic developments in their decisions. This may motivate them to study economics more in depth.

Most macroeconomic simulation games are focused on understanding the model in the game. Games that have interaction between the players simulate only a limited number of periods (Santos 2002; Gremmen and Potters 1997) and normally include interactions between governments or countries instead of companies. Even in those games it is at least as important to understand the model as to understand the behavior of the other players. In "Steer the Economy" a system has been created where micro- and macroeconomic dynamics are the consequence of the interaction between the decisions of the players within an environment that is as lucid for the players as possible.

\section{BACKGROUND OF THE MODEL}

The model is based on a two-sector growth model with sector-specific capital that can not be shifted between the investment goods sector and the consumption goods sector once it is installed (Inada 1966 Van Marrewijk and Verbeek 1993). The players make all company decisions. Each group of players simulates one company on 
one or more computers where they have to make their decisions and analyze the game results. The other actors, i.e. consumers, employees, government and a Central Bank, are included in the computer model and can be influenced by the game leader.

Problems of irreversibility of decisions are very important in explaining economic instabilities. A putty-clay production function for the machines and the lack of substitution between investment and consumption goods make expectations very important. Furthermore, institutions and the behavior of the players replace the equilibrium conditions of the growth model. This makes the game a general disequilibrium game, where processes towards or away from equilibrium in the markets for consumption goods, investment goods, and labor are the consequence of the decision of the players. To allow for disequilibrium explicit buffers like inventories and delivery times of machines had to be introduced.

In order to make the decision environment more or less real time, the decision period has been set rather short, i.e. a month, while the simulation period in a normal game is between 10 and 15 years. This implies about 150 decision periods per game in contrast to five till ten decision periods in most other simulation games. The short decision period implies that the time per period is short, about a minute per period, to be set by the game leader. It is not necessary that the players make decisions every game month. When for example the price is not changed, the program uses the old price. Players also have an opportunity to set trend values. For example, prices may be set as a fixed percentage of the average market price of the month before. Players feel the game therefore more or less as a continuous process. During the game they will get a feeling for the strategic consequences of their decisions.

\section{SKETCH OF THE GAME MODEL}

This section presents an intuitive description of the game model. This description is more or less complete and shows that the model can be explained in an intuitive way for the players. During the description we will refer to opportunities to show the relationship between economic theory and the game. For a more formal description, see Woltjer (1995) and Woltjer (2003).

The game simulates an economic system just as the world economy is an economic system, although it is much simpler. All companies playing the economy game concurrently are interlinked through a computer network, so that the cumulative efforts of each player represent the general economy's movements.

The macro-economy consists of four markets: a market for consumption goods, a labor market, a market for investment goods and a credit market. There are five main types of actors: companies, consumers, employees, 
banks and governments. The computer model (managed by the game leader) simulates the decisions of the consumers, employees, banks and governments. The players make all the company decisions, i.e. sales price, wage, labor demand and investment.

At the start of the game, the players are in charge of an operational business. This business is partly equity financed and partly financed by liabilities. There is no market for equity, so that the only way in which a company can enlarge its equity is by means of retained earnings. There are no taxes. Liabilities can be borrowed at an interest rate that is determined by the Central Bank. The opportunity cost of capital, i.e. the interest rate, is paid as dividend to the shareholders. The rest of profits adds to equity capital.

The mission of the companies is to maximize the value of their companies by the end of the game. This value consists of equity, which can be directly observed on the balance sheet, and 'goodwill', which is an estimate of the net present value of future profits. There are two types of companies: for consumption goods and for machines. Machines are ordered implicitly from the machine companies, i.e. other players. Aggregate consumer demand is calculated as a function of labor income, non-labor income, the interest rate and inflation.

Companies produce final goods with the help of labor and machinery. There are different types of machines. More labor-intensive machines can produce more output with the same amount of capital, but labor productivity decreases. Players can investigate the exact relationship between machine type and production capacity of the machines in the so-called 'Calculator for the company'. The graph presented there illustrates the law of diminishing marginal returns. The calculator also provides an opportunity to calculate the optimum type of machine at different factor prices. Machines last only for a limited period of time. In the standard cost calculations, machinery is linearly depreciated, but players may do otherwise. During the time that machines are operational, they have full production capacity; after that period they produce nothing at all. When machines operate at less than full capacity, the production of a machine is lower; the exact relationship between labor use, production, variable cost and price can be seen in the 'Calculator for the company'. The computer program automatically allocates labor in the most efficient way.

Machines are bought on the market for investment goods. The decisions of all the players together determine the demand for machines. The delivery time of machines depends on the production capacity of the machine companies and the number of orders they have in portfolio. In order to base investment decisions on reliable information, a fictitious mediator buys the machines from the machine companies and sells them to the companies according to an average of the conditions set by all machine companies. 
Aggregate labor supply grows at a constant rate, and normally the game leader sets this rate at $0 \%$. Demand for labor is determined by the players' decisions. Filling vacancies takes at least one month. All people in the labor force have a reservation wage that more or less follows the trend in average wage. If the labor market is tight, however, most unemployed people will have a high reservation wage compared with average wage and will not be inclined to accept a job very easily. In that case a company will mainly have to recruit people by luring them away from other companies by offering a higher wage. Furthermore, also without direct competitors available, $1 \%$ or more of the company's employees will leave the company because of retirement or other reasons.

The two types of companies differ mainly on the characteristics of their output market. A consumption goods company produces on stock. The size of total sales equals the minimum of demand and inventory plus production. Consumer companies more or less have a pool of regular customers. As long as they keep the price at the average market price, these customers will not leave. If, however, they set their price higher than that of their competitors, they will lose customers. Market research in the game has shown that setting your price $1 \%$ above the average price will lead to a loss of market share of approximately $3 \%$ per year. This type of information helps players to think with the elasticity concept.

Machine companies mainly produce according to the orders they receive. A fictitious mediator divides the machine orders over the machine companies. In doing this, the mediator checks the offers of three randomly chosen companies and takes the one with the best combination of relative prices and delivery time. A company with a higher goodwill (i.e. market share during the last five till ten years) has a higher probability to be asked for an offer. Because attractiveness of a machine is determined by a combination of expected delivery time and price it is not useful for a machine company to compete very strongly on price when it has a long delivery time.

The capital market is very simple. There is no market for equity. Liabilities can be acquired at a variable interest rate set by the Central Bank. The default policy of the Central Bank is monetarist in character and tries to increase the real interest rate with increasing inflation. When a company's capital position deteriorates considerably, borrowing may no longer be possible. Besides, there are all kinds of restrictions on investment credits, such as a minimum utilization rate of the company's machines and a maximum growth rate of its stock of machinery per month.

The game leader manages government. Government may decide about government consumption or investment in order to curb a Keynesian recession, but normally government expenses are set at 0 in order to focus the game on market dynamics instead of predicting mistakes by government. The game leader may also set 
minimum and maximum prices, minimum and maximum wages, conditions for investment credits and the interest rate. The game has implemented these policy variables as restrictions for decision-making in order to prevent that one or two companies cannot disturb the whole economy by making very irrational decisions. The game leader may watch graphs showing how many companies are limited in their freedom by the restrictions and may decide to loosen those conditions when necessary.

\section{A GLIMPSE AT THE INTERFACE}

In order to get a better idea of the game, we will shortly discuss the main form of the interface for the players (figure 1). The left window shows variables of the economy and its sectors. Players can look back, make graphs from these variables with one right-mouse click and also put other variables on the window. The right window shows information about the company and provides the opportunity to enter decisions by double-clicking on a decision variable presented in the tab sheet 'Decisions'. Information about decisions is presented in the 'Decision Restrictions' part, where an asterix indicates the variable where a restriction is active. The other tab sheets show overviews of a lot of aspects of the company. There is also an opportunity to generate graphs like figure 13 comparing the company with the average of the sector.

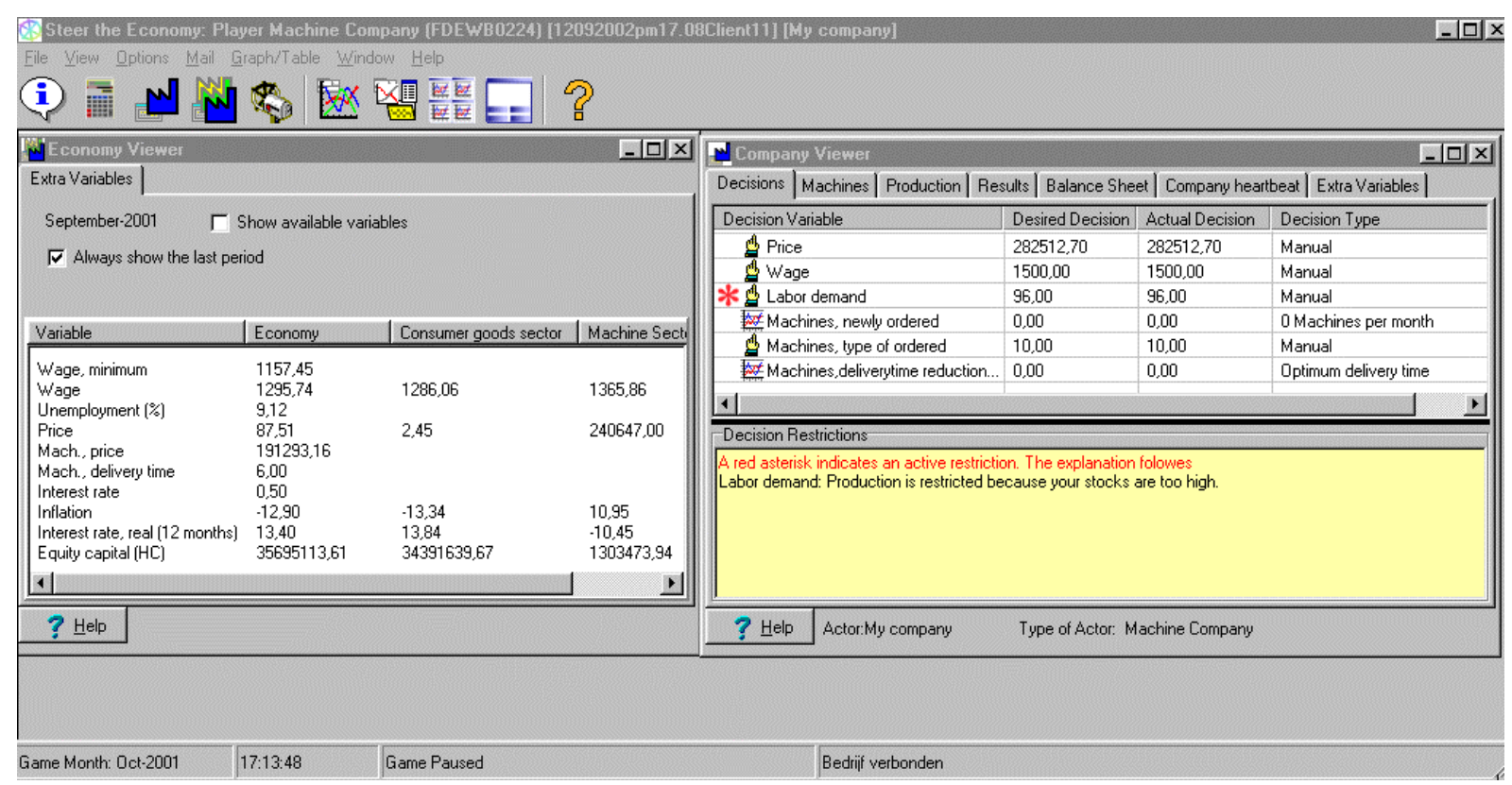

Figure 1 The main window for the players

The main menu gives the opportunity to open the different viewers including the 'Calculator for the Company', to open standard graphs and to make your own graphs and tables. 


\section{INTERPRETATION OF GAME RESULTS}

This section shows a simple macroeconomic analysis and a simple company analysis in order to give an idea what you can get out of game like this. It illustrates the dynamics of the game model and shows how to use the information in the game and how it can be related to economic theory. But the spectrum of possibilities to analyze the results is much larger.

In order to show that the dynamics of the game is determined completely by the behavior of the players, we discuss two games. The two games have been played by the same group of students in Economics and Business Administration at Universiteit Maastricht at the end of the first year of their study. Both games consist of 25 companies managed by two or three students. The only difference between the two games is the behavior of the players. The first one was played on June $13^{\text {th }} 2002$ and the second on June $20^{\text {th }}$. The students played the first game without other preparation than reading the manual. Therefore, the dynamics of this game is mainly the consequence of irrational decision-making by the players. During the week between the games they had to analyze the first game by making graphs as shown below, and prepare a paper about the game. They had to formulate their company strategy for the second game. Then they played the game with a better strategy and wrote a final paper about the game. It is obvious that the game can be used in a lot of other ways.

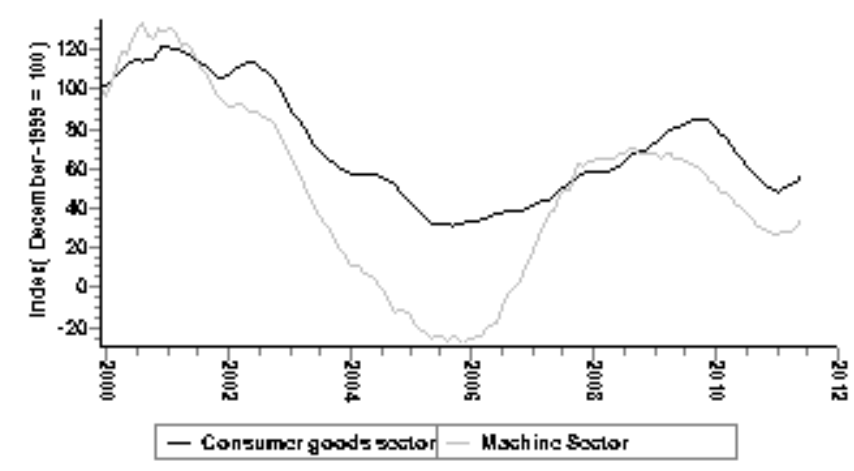

Figure 2 Real equity capital (first game)

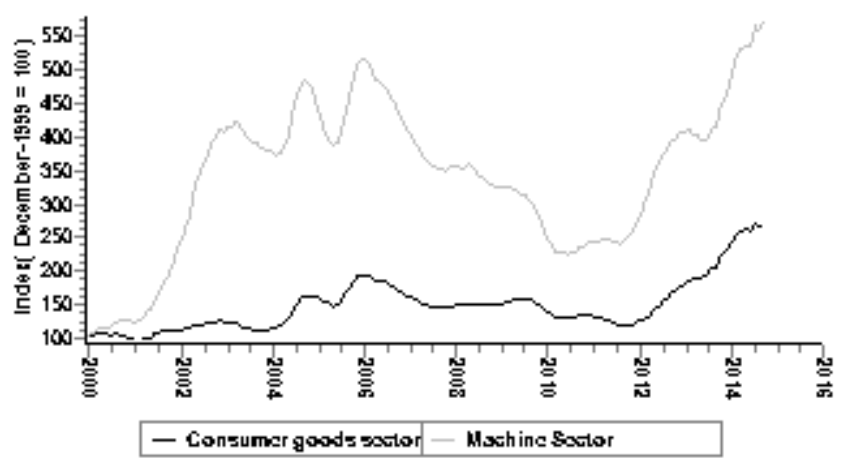

Figure 3 Real equity capital (second game)

Players are expected to improve their insights into macroeconomic dynamics. Figures 2 and 3 show that the development of a variable like real, i.e. inflation corrected, equity capital is much better in the second game than in the first game. In the first game the average of the machine sector had negative equity capital, i.e. was bankrupt, around 2006, while the consumption goods sector did better, although their real equity capital decreased. In the second game both sectors developed well, while the machine sector did best of the two.

The graphs 'Inflation' (figures 4 and 5) provide a partial explanation for these differences. During the first game machine companies were competing very strongly on price at the start of the game, while machine demand 
was extremely high as shown by the high delivery time of machines. In the second game machine companies set higher prices, and the companies reacted to that by lower investment. Because the intermediate machine trader evaluates the offers of the machine companies on a combination of price and delivery time, as long as the delivery time of your product is long it is not very wise to compete so much on price that price is below cost price. Figure 6 illustrates this: in July 2004 of the first game one company is selling a machine at a price of $\$ 550,000$, while another is getting only $\$ 440,000$. Because the cost price is more than $\$ 512,000$, the company with low price is selling at huge losses. So, the game both teaches how to improve price setting in different phases of the business cycle and shows them how price-setting behavior of the companies has consequences for the whole economy.

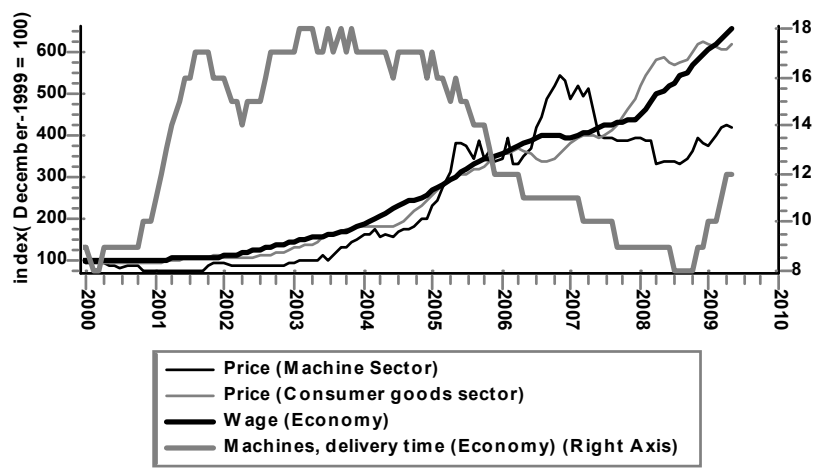

Figure 4 Inflation (first game)

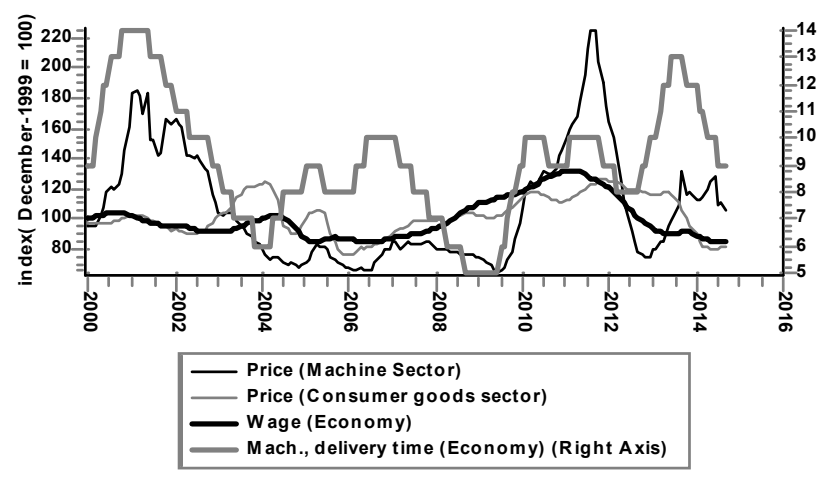

Figure 5 Inflation (second game)

At the start of the second game machine companies set very high prices as a reaction on increasing machine demand, as can be seen in the increase of the delivery time of machines (figure 5). Because of the high machine price consumer goods companies reduced investment. The machine companies seem to overreact on the decrease in demand by setting very low prices at the cost of profitability. This explains the decrease in real equity capital of the machine sector between 2006 and 2010. When the delivery time increased, price was again rather high. So, this graph can be used to show how price and delivery time can be used as indicators of profitability and demand. 


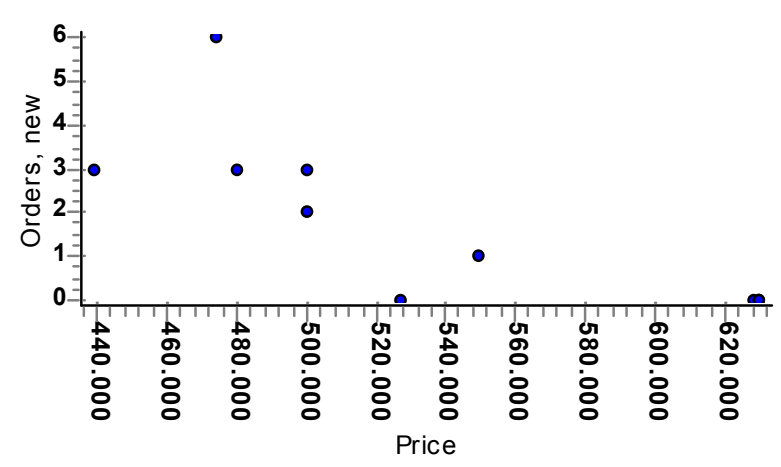

Figure 6 Price and new orders (first game July 2004)

The consequence of high investment at the start of the first game can be found back in a very tight labor market. Around 2004 labor demand was 25\% above labor supply (figure 7). This shortage on the labor market explains the high inflation rate in the first game (figure 4). As a consequence of the overcapacity, investment had to be low for a long time. If companies had known the problem of labor shortage in advance, then they would have invested less. As a consequence, the labor shortage would have been less and the period for solving the problems of labor shortage would have been shorter. This shows the relevance of expectations for economic dynamics and the profitability of the companies.

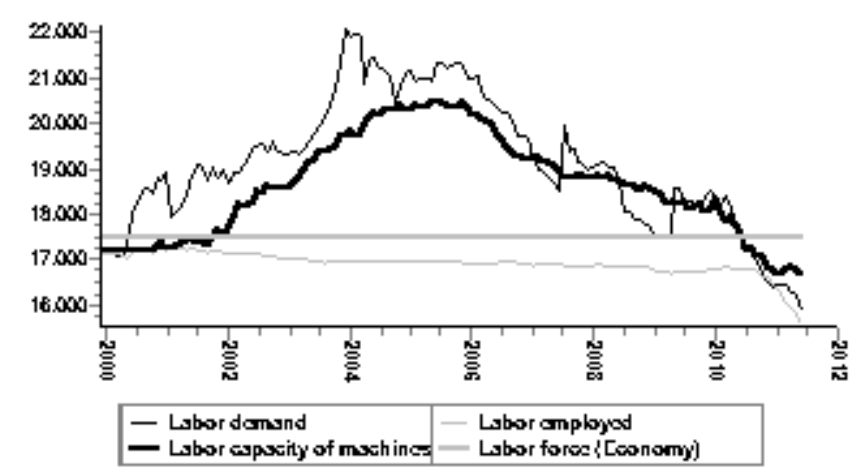

Figure 7 The labor market (first game)

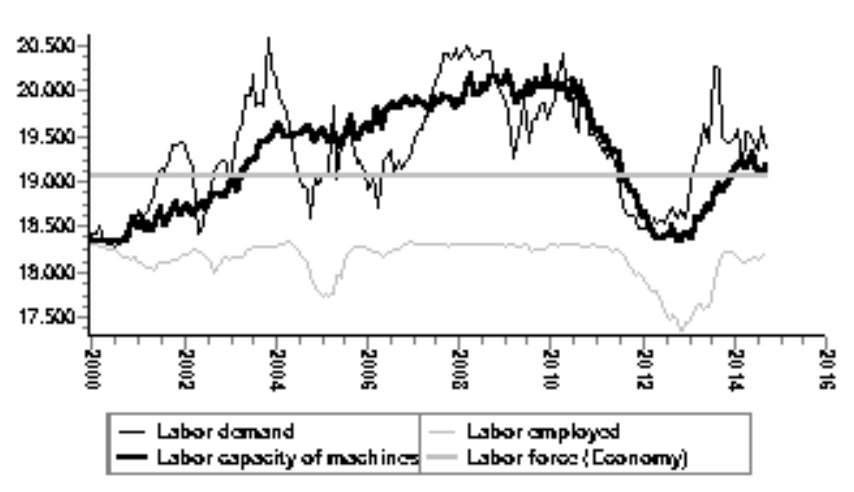

Figure 8 The labor market (second game)

Figure 8 shows that the students learned from the first game. Labor shortage is never above $10 \%$ of labor supply. Labor capacity of machines is the amount of labor that can be used on machines at a normal utilization rate. Labor demand, i.e. the sum of all labor demand decisions by the players, more or less follows labor capacity and most of the time there is more labor demand than supply. The short periods of unemployment in the second game (figure 10) are the consequence of shifts of labor from one company to another, i.e. the consequence of adjustment processes within the economy. This can be seen in figure 10, where in many periods the vacancy rate 
changes in the same direction as the unemployment rate. In the first game (figure 9) the high unemployment rate at the end of the game is combined with a low vacancy rate. The quantitative shortage of labor demand is caused by a combination of a lack of aggregate demand and insufficient capacity of the machines. So, unemployment in the first game is both Keynesian and structural in character. In this way, the game gives the opportunity to discuss different causes of unemployment

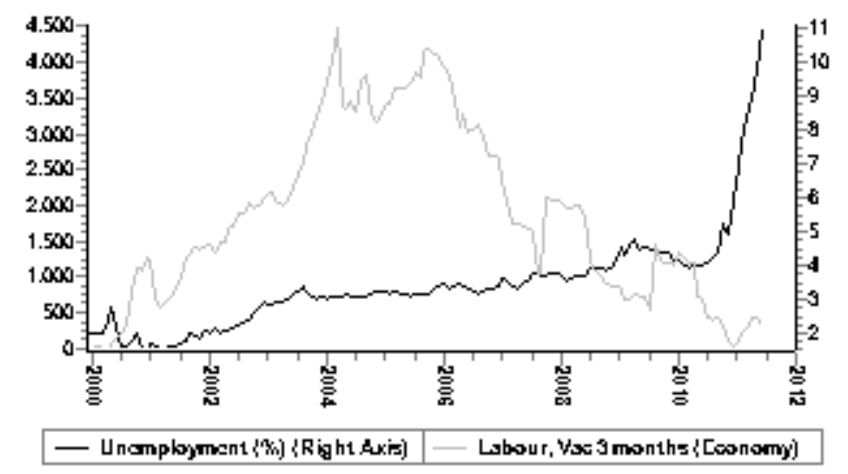

Figure 9 Unemployment and vacancies (first game)

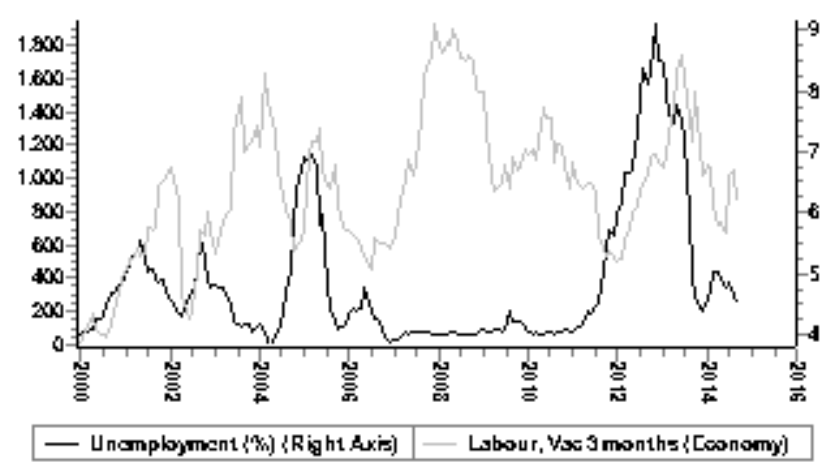

Figure 10 Unemployment and vacancies (second game)

It is obvious that capital-intensive investment can be wise in periods with a shortage of labor. In the first game the machine type becomes less labor intensive towards the middle of the game when the vacancy rate becomes very high, and becomes more labor intensive when the vacancy rate becomes lower (figures 9 and 11). The players may analyze the relationship between relative factor prices and labor intensity of production, but they will also become aware that this relationship is more complex than assumed in introductory textbooks because it depends on expectations about future factor prices as well as possible shortages that are not immediately translated into factor prices. Furthermore, they may become aware of the advantage of having some labor-intensive machines in their machine park because they are cheapest to switch on and off when demand fluctuates. 


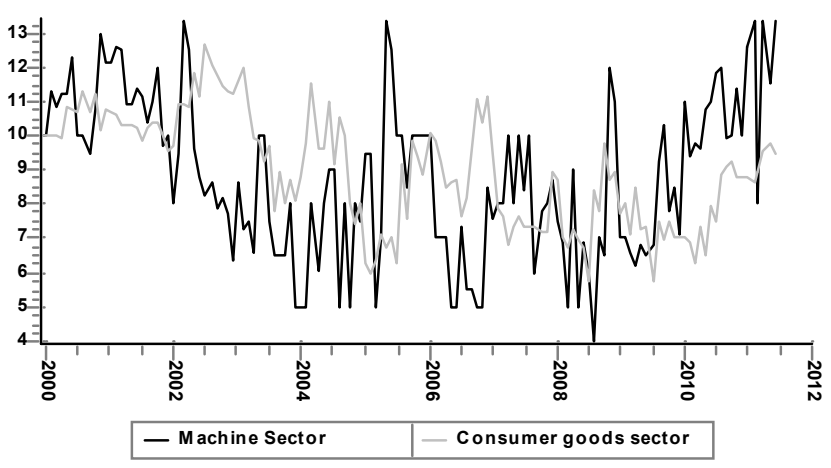

Figure 11 Machine type (first game)

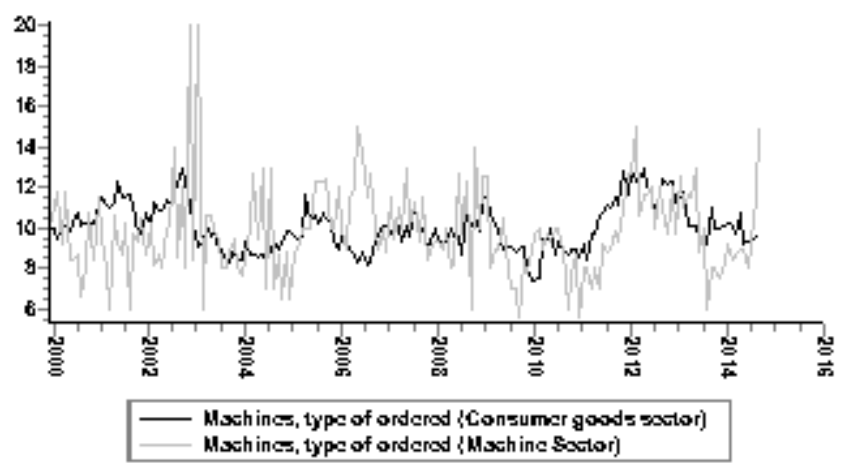

Figure 12 Machine type (second game)

Till here the analyses was macroeconomic in character. But macroeconomic performance is the consequence of microeconomic decisions, while firm performance is also interesting in itself. Therefore, let us analyze company performance of two companies in the second game. First, we take consumer company Tankraft. This company was the best company at the end of the game. During the first two years Tankraft had a bad position with respect to equity capital. This was a consequence of its long-term expansionary strategy. Tankraft expanded its market share with $25 \%$ (figure 13) by high investment in machines (figure 14). At the start of the game the company needed a very low price to increase its market share, but the rest of the game it could use its goodwill and in general set a higher price than the average company (figure 14). In the labor market Tankraft had to compete by setting a higher wage during its expansion. Because it was setting an extremely low rate at the end of 2001, the vacancy rate increased fast with a low utilization rate of machines as a consequence. Setting a much higher wage during 2002 solved this problem (figure 15). So, at the start of the game Tankraft was focused on long-term profits by gaining market share both at the output and labor market, but at the cost of short-term profits. It is obvious that this strategy did only work out because not all companies were doing this. 


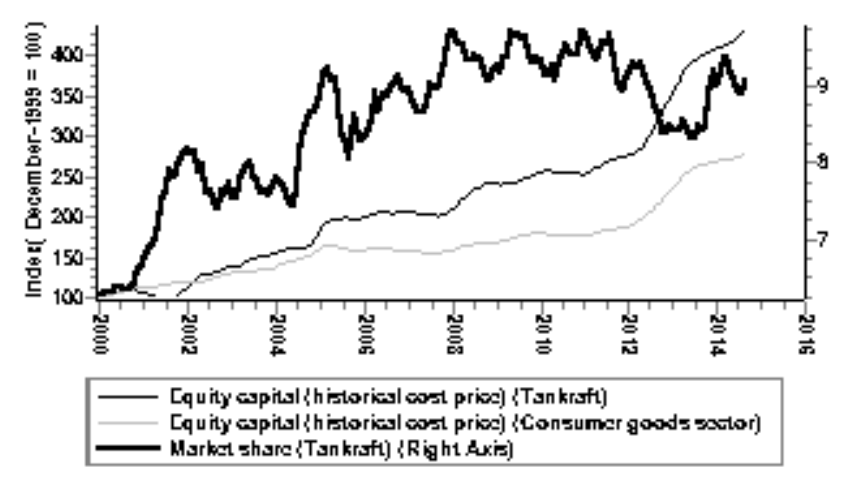

Figure 13 Equity capital and market share

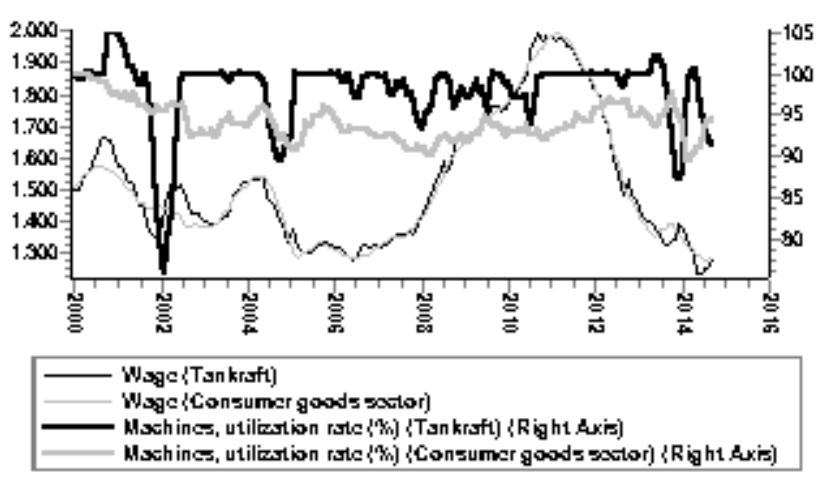

Figure 15 Wage and utilization rate of machines (\%)

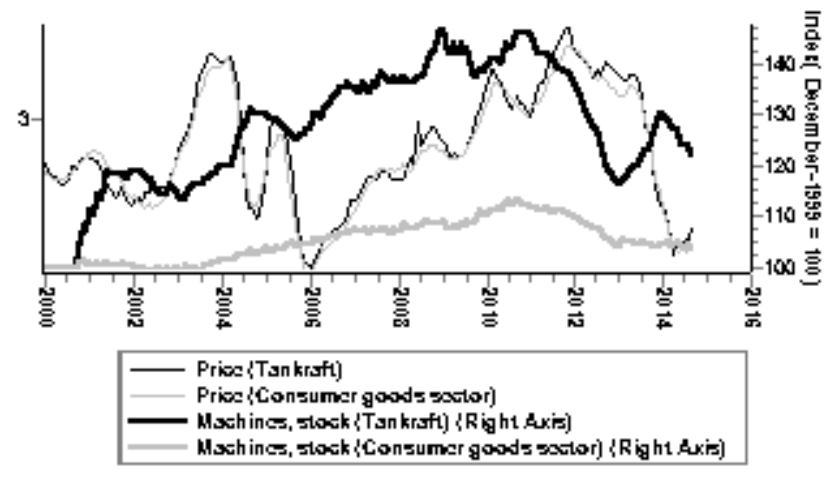

Figure 14 Stock of machines and sales price

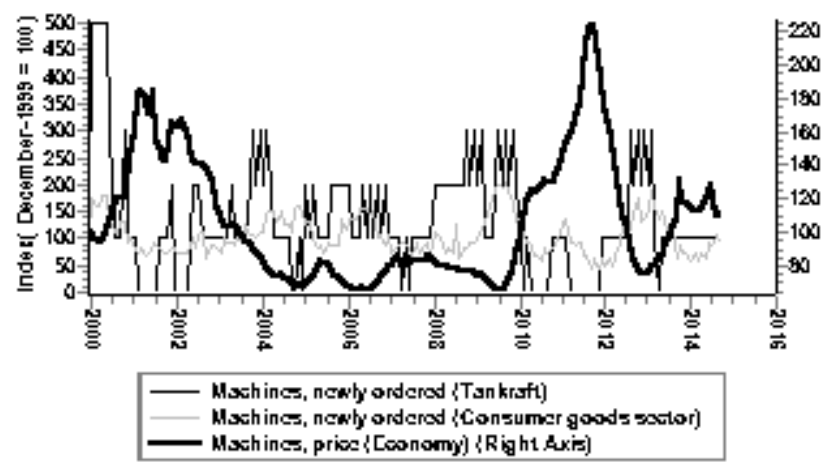

Figure 16 Machine price and newly ordered machines

The timing of investment shows another feature of Tankraft's success. While most other expansive companies did invest also in periods with a very high machine price, Tankraft did invest more than average in periods when the machine price was relatively low, while it invested less than average in periods with high prices of machines (figure 16). At the end of 2001 and 2011 machine price was almost double the cost price of machines, implying that the speculative risk of investment was extremely high. Low investment in those periods has prevented revaluation losses for Tankraft. This shows how important it can be to invest anti-cyclically and to be alert to the reasonableness of prices of investment goods. 


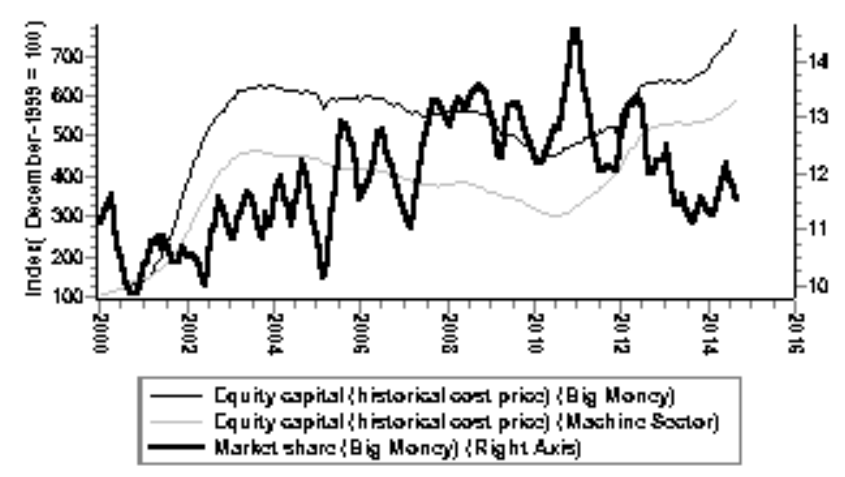

Figure 17 Equity capital and market share

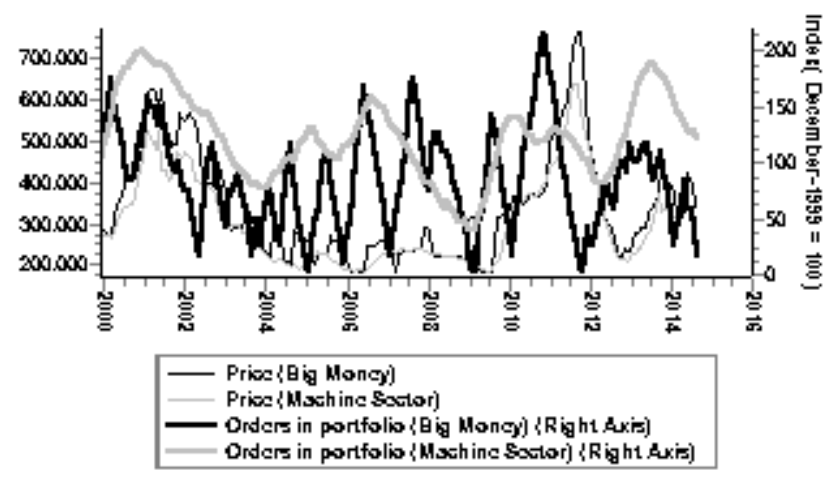

Figure 18 Orders in portfolio and sales price

The best machine company was Big Money. This company had a fast increase in equity capital at the start of the game, but then lost part of its position despite an increase in market share (figure 17). Big Money started with a very fast increase in output price. This was beneficial because most investors were not very wise and did not react to those high prices. During most of the game Big Money had relatively high output prices compared with the average company. Only when orders in portfolio were low Big Money panicked and sharply decreased its price (figure 18). The fast increase of orders in portfolio after each price decrease shows that Big Money was overreacting.

Figure 19 shows how Big Money was able to create a utilization rate of $100 \%$ most of the time by setting a relatively high wage. Each period the company experimented with a much lower wage than average, its utilization rate of capital decreased very fast.

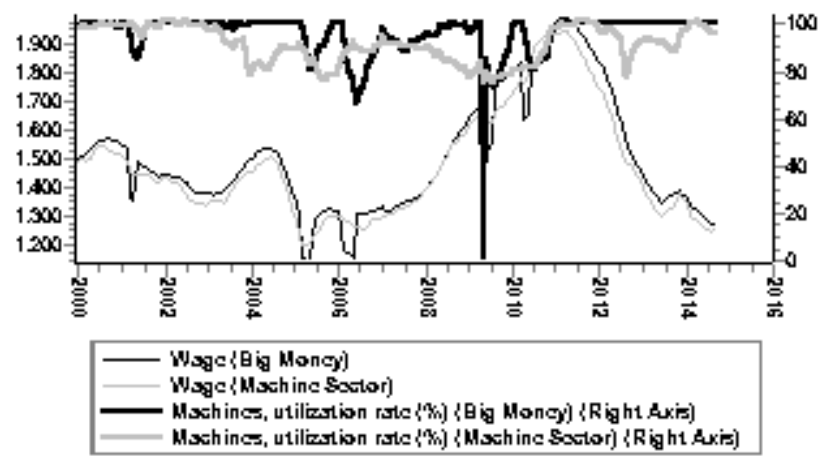

Figure 19 Wage and utilization rate of machines (\%)

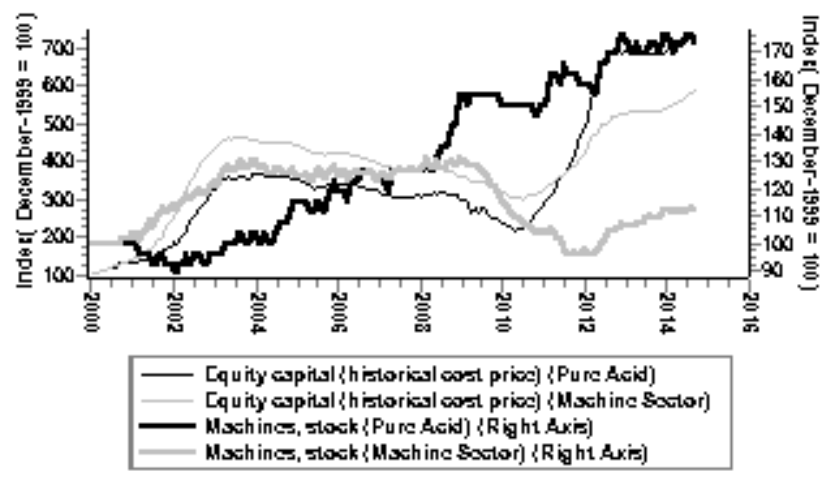

Figure 20 Equity capital and stock of machines of another company

In order to show the relevance of investment policy, the machine company "Pure Acid" that became second in the game may be interesting to see (figure 20). This company expanded a lot after 2007. This had no benefit at 
all in normal situations, but gave a huge opportunity at the moment when machine demand was very high around 2011. This implies that it would have been beneficial for machine companies to invest a lot before the large price increase. And probably this would have helped to stabilize the economy because in that case there would have been more capacity in the machine sector to adjust for extra demand. This shows the importance of good predictions of future changes in demand and supply for both company profits and macroeconomic performance. And this may be an incentive for the players to investigate more in depth the fundamental forces that determine macro- and microeconomic dynamics.

\section{FEEDBACK TO THE PLAYERS}

Even if a game provides interesting results for people who are able to interpret the results, it is useless for teaching when students are not able to analyze the causal relationships in the economy and don't understand what they are doing. Feedback is an essential ingredient for a good simulation game, but is also very difficult to accomplish.

The best feedback is providing relevant information in such a way that the students can find out things for themselves. For this purpose a number of standard graphs and overviews have been developed. On some of those overviews, a number is presented in a different color when a variable reaches a dangerous zone. For example, when the stock of products becomes 0 it is shown in red instead of black. Furthermore, it has been made very easy to present historical data of a variable presented in one of the overviews by a right mouse click. A game leader provided feedback simply by showing one in his eyes important graph of the game on the beamer. He got the most stable game economy we ever had. All of these features may provide incentives and opportunities for the players to think for themselves about their strategy. But experience shows that they are far from enough. 


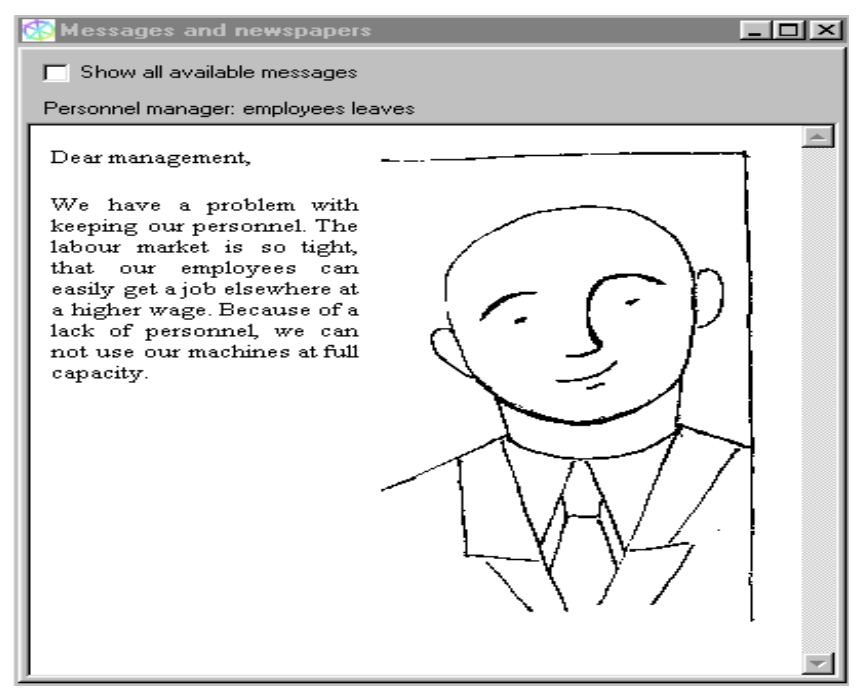

Figure 21 An example of a warning

A more direct way of feedback is the automatic generation of messages under specific conditions. For example, when employees leave the company a message from the personnel manager may appear where he warns for this problem (figure 21). Our experience shows that this type of messages can prevent the most stupid mistakes, but that you have to be very careful not to send too many of them. In that case, players just close the message windows without reading the messages.

The game leader can also send questions to all players or a selection of players during the game. Asking questions during a break of the game is a more direct way to help students think about causalities in the economy and argumentations for their policies. But our experience shows that a reward for good answers and a break of sufficient length is necessary for students to work seriously on the answers. Both based on the feedback forms of the players and our own experience, we decided to split up the games into more sessions where the players can work on assignments in between. We expect that this will force students to analyze what happens more in depth and that this will improve their ability to use macroeconomic analysis for the policies of their companies. The advantage of using questions is that the players have to formulate their thoughts and that the game leader is able to get an insight into what the students understand. Sometimes, the answers of the players may be an occasion for the game leader to give more specific questions or feedback.

Central explanation with the help of a beamer is a last way of feedback. It requires that the players are in one room. When the game leader explains too much, this is dangerous, because it may influence decision making systematically. Furthermore, it makes the game leader do the work instead of the students. Just as with normal lectures, it is disappointing how little of the insights provided by a central explanation of the game leader is used by the players. 


\section{CONCLUSION}

The game "Steer the Economy" has been designed to create a macroeconomic decision environment for players as companies, where the interaction between their decisions determines to a large extend the outcomes and the environment is both intuitive and easy to overview for the players. A game like this provides a lot of opportunities to analyze the results in a relevant way, both from a theoretical point of view and from the point of view of a company. It gives an incentive to analyze the macro-and microeconomic environment of the company and teach them to make decisions from a long-term perspective. It provides a lot of opportunities to analyze the results in a relevant way. But without adequate feedback it is not easy to do such an analysis and therefore the students will not do it. This feedback has to be carefully designed. By varying the type and theoretical content of the feedback, the game can be used for a lot of different levels of theoretical knowledge and both from a business perspective and from a pure economics perspective.

\section{REFERENCES}

Goeree, J.K., and C.A. Plott. 1999. Employment and Prices in a Simple Macroeconomy. Southern Economic Journal 65 (3): 637-647.

Gremmen, H., and J. Potters. 1997. Assessing the Efficacy of Gaming in Economic Education. Journal of Economic Education 28 (Fall): 291-303.

Inada, K. 1966. Investment in Fixed Capital and the Stability of Growth Equilibrium. Review of Economic Studies 33: 19-30.

Marrewijk, C. van and J. Verbeek. 1993. Sector-specific Capital, "Bang-bang" Investment, and the Filippov solution. Journal of Economics 57: 131-146.

Meister, J.P. 1999. Oligopoly - An In-Class Economic Game. Journal of Economic Education 30 (Fall): 383391.

Millerd, F.W. and A.R. Robertson. 1987. Computer Simulations as an Integral Part of Intermediate Macroeconomics. Journal of Economic Education 18 (Summer): 269-286.

Santos, J. 2002. Developing and implementing an internet-based financial system simulation game, Journal of Economic Education 33 (Winter):31-40.

Truscott, M.H., H. Rustogi and C.B. Young. 2000. Enhancing the Macroeconomics Course: An Experiential Learning Approach. Journal of Economic Education 31 (Winter): 60-65. 
Woltjer, G.B. 1995. Coordination in a macroeconomic game. Universitaire Pers Maastricht, Maastricht, The Netherlands.

Woltjer, G.B. 2003. An agent-based simulation game for research on macroeconomic coordination. Meteor Research Memorandum, Maastricht, forthcoming.

Yoho, D.L. 1989. Fairmodel: Microcomputer Software to Teach Macroeconomic Concepts. Journal of Economic Education 20 (Winter): 107-113.

${ }^{1}$ From the same perspective much simpler experimental games have been designed. See for example Goeree and Holt 1999. 